\title{
ESTIMATION OF PHENOTYPIC AND GENETIC TRENDS OF THE GROWTH TRAITS IN LIPSKA AND SVRLJIG SHEEP
}

\author{
V. Caro Petrović ${ }^{1 *}$ M. P. Petrović ${ }^{1}$, M. M. Petrović $^{1}$, Z. Ilić ${ }^{2}$, N. \\ Maksimović, D. Ružić Muslić ${ }^{1}$, N. Stolić ${ }^{3}$ \\ ${ }^{1}$ Institute for Animal Husbandry, Belgrade, Serbia \\ ${ }^{2}$ Faculty of Agriculture, Lesak, Serbia \\ ${ }^{3}$ Highshool of Agriculture, Prokuplje, Serbia \\ *Corresponding author: V. Caro Petrovic, e - mail: violycaro@yahoo.com \\ Original scientific paper
}

\begin{abstract}
Some phenotypic and genetic trends on growth traits of lambs are observed. The research implicated lambs of two local breeds of sheep: Lipska (LP) and Svrljig (SV). All lambs were weighed for the first time at birth (BWB), and thereafter, regularly in two-week intervals. On the basis of the results during weighing the body weight (BW) were adjusted to the average age: 30 (BW30), 60 (BW60) and 90 days (BW90). Results of the effect of genotype on growth showed a significant effect on the growth traits. Sex of lambs had a significant effect at birth and very significant effect at 30 days, but had no significant effect on weight at 60 (BW60) and 90 (BW90) days. Birth type had significant effect on the body weight from birth to weaning and the highest body weights were recorded in singles. Phenotypic correlations were positive and very highly significant between the growth traits. Genetic correlations were significant, but not between all observed ages of lambs.
\end{abstract}

Key words: lamb, phenotype, genetic trend, growth traits

\section{Introduction}

Sheep population of the Serbia was estimated to be 1.5 million head in 2012 (Agricultural Statistics). All sheep breeds of the country are divided between indigenous or local and more productive breeds, which are mainly imported from the Western Europe. Local Lipska and Svrljig breeds are very important for production of lamb meat and milk (Petrović, 2007), but for their future improvement we need to know level of different factors affecting production.

To obtain reliable estimates of inheritance pattern for important economic traits and to increase the accuracy of selection of breeding animals, adjustment of 
data for many factors for the various traits are necessary (Ugarte, 2007). The effect of various factors like genotype, type of birth, sex of lamb on lamb growth traits in this breeds have not been studied earlier.

The early growth traits (birth and weaning weight) are important in productivity and are the major selection traits in sheep breeds known to be influenced by genetic and environmental factors (Mandal et al., 2003; Behzadi et al., 2007, Dass et al., 2008). Information on the relative performance of indigenous sheep breeds can vary from year to year. It is, therefore, important to investigate the effects of various factors on the variation among animals in order to find efficient breeding plans to improve production. Information on the genetic and environmental aspects of productive performance of Lipska and Svrljig sheep is not available. Therefore, the objective of this study was to evaluate the phenotypic and genetic trends on growth traits for Lipska and Svrljig breeds of sheep.

\section{Material and methods}

The research involved lambs of two local breeds of sheep: Lipska (LP) and Svrljig (SV). In this study 360 lambs (60 lambs per classes) were included. All lambs have weighed for the first time at birth (BWB), and thereafter, regularly in two-week intervals. Determinations of weight carried out to the nearest $0.1 \mathrm{~kg}$.

On the basis of the results during weighing the body weights (BW) were adjusted to the average age: 30 (BW30), 60 (BW60) and 90 days (BW90) by using a linear interpolation method.

The management system used the traditional method of sheep husbandry in the area, in terms of grazing and supplementation. The male and female lambs remained with their mother until weaning at 90 days and fed ad libitum with hay and concentrate with $18 \%$ of protein.

The recorded data analyzed statistically using the least-squares method (Harvey, 1991). The systematic effects were genotype, sex and type of lamb birth. For statistical calculations, the following linear model equation was use:

$\mathrm{Yijk}=\mu+\mathrm{Gi}+\mathrm{Sj}+\mathrm{Bk}+$ eijk

where:

Yijkl $=$ measured trait

$\mu=$ overall mean

$\mathrm{Gi}=$ effect of the $\mathrm{i}^{\text {th }}$ genotype (fixed effect -2 classes)

$\mathrm{Sj}=$ effect of the $\mathrm{j}^{\text {th }}$ sex (fixed effect -2 classes)

$\mathrm{Bk}=$ effect of the $\mathrm{k}^{\text {th }}$ birth type (fixed effect -2 classes)

eijk $=$ residual error 


\section{Results and discussion}

Results on the body weight of lambs at birth (BWB) and 30 days (BW30) are shown in Table 1.

It is evident from Table 1 that the average birth weight of the LP lambs was $4.91 \mathrm{~kg}$ and the average 30 -day body weight was $13.89 \mathrm{~kg}$. The average birth weight in SV lambs was $3.89 \mathrm{~kg}$ and $10.29 \mathrm{~kg}$ at 30 days. Can be seen, a very significant effect of genotype $(\mathrm{P}<0.01)$ on body weight in both the control periods.

The evaluation of the effect of sex on growth showed above all that this factor had a significant effect $(P<0.05)$ at birth and very significant effect at 30 days $(\mathrm{P}<0.01)$. Male lambs were heavier than female.

Type of birth has also effect on the body weight of lambs at birth $(\mathrm{P}<0.05)$ and at 30 days $(\mathrm{P}<0.01)$.

Laes-Fettback and Peters (1995) stated that birth weight of lambs is affected by litter size. Notter et al., (1991) have also reported that birth weight of lambs is greatly influenced by production system, lamb sex, ewe effects and ewe $\mathrm{x}$ season interaction.

Dixit et al. (2001) found the effect of sex and the birth type statistically significant on the weight of lambs. This result was in conformity with the results of the present study.

Table 1. Body weight of lambs at birth and 30 days

\begin{tabular}{|c|c|c|c|c|}
\hline \multirow[t]{2}{*}{ Effect } & \multicolumn{2}{|c|}{ BWB } & \multicolumn{2}{|c|}{ BW30 } \\
\hline & Mean & S. E. & Mean & S. E. \\
\hline \multicolumn{5}{|l|}{ Genotype } \\
\hline LP(A) & $4.91^{\mathrm{B}}$ & \pm 0.15 & $13.89^{\mathrm{B}}$ & \pm 0.40 \\
\hline SV(B) & $3.89^{\mathrm{A}}$ & \pm 0.11 & $10.29^{\mathrm{A}}$ & \pm 0.29 \\
\hline \multicolumn{5}{|l|}{ Sex } \\
\hline Female(A) & $4.37^{b}$ & \pm 0.13 & $11.45^{\mathrm{B}}$ & \pm 0.32 \\
\hline Male(B) & $4.43^{\mathrm{a}}$ & \pm 0.13 & $12.70^{\mathrm{A}}$ & \pm 0.33 \\
\hline \multicolumn{5}{|l|}{ Birth type } \\
\hline Single(A) & $4.52^{b}$ & \pm 0.12 & $12.95^{\mathrm{B}}$ & \pm 0.30 \\
\hline Twins(B) & $4.28^{\mathrm{a}}$ & \pm 0.14 & $11.20^{\mathrm{A}}$ & \pm 0.33 \\
\hline
\end{tabular}

A,B $P \leq 0.01 ;$ a,b $P \leq 0.05$ 
Least-squares means and standard errors of body weights at 60 (BW60) and 90 days (BW90), in according to genotype of lamb, sex and birth type are presented in Table 2.

The evaluation of the effect of genotype on growth showed above all that this factor had a significant effect $(P<0.01)$ at 60 (BW60) and 90 days (BW90). El-Fadilli et al. (2000), Suarez et al. (2000), and Margetín et al. (2004) reported that the genotype significantly influenced the majority of growth traits.

Sex of lambs had no significant effect $(\mathrm{P}>0.05)$ on weight at 60 (BW60) and 90 (BW90) days. Such results are in accordance with those results reported by Petrović et al. (2011) in Pirot and Svrlig breeds of sheep.

Birth type had a significant effect $(\mathrm{P}<0.05)$ on body weights under study, and the highest body weights were recorded in singles. This is in agreement with the results by Fernandes et al. (2001) and Kuchtik and Dobes (2006).

The analysis of phenotypic correlations (Table 3 ) indicated that BWB and BW30 showed a positive and very highly significant $(P<0.01)$ effect on the other body growth traits under study. This is in agreement with the results of Dixit et al. (2001) and Kuchtik and Dobes (2006).

In the same table, it can be seen that the genetic correlations were less and very significant $(\mathrm{P}<0.01)$ between $\mathrm{BWB}$ and $\mathrm{BW} 30$ and significant $(\mathrm{P}<0.05)$ only between BWB and BW60 and BW30 and BW60.

Table 2. Body weight of lambs at 60 and 90 days

\begin{tabular}{|l|c|c|c|c|}
\hline \multirow{2}{*}{} & \multicolumn{2}{c|}{ Bffect } & \multicolumn{2}{c|}{ BW90 } \\
\cline { 2 - 5 } & Mean & S. E. & Mean & S. E. \\
\hline Genotype & $21.23^{\mathrm{B}}$ & \pm 0.71 & $27.91^{\mathrm{B}}$ & \pm 0.77 \\
\hline LP(A) & $16.35^{\mathrm{A}}$ & \pm 0.55 & $24.95^{\mathrm{A}}$ & \pm 0.55 \\
\hline SV(B) & 18.45 & \pm 0.61 & 26.02 & \pm 0.65 \\
\hline Sex & 19.13 & \pm 0.63 & 26.84 & \pm 0.64 \\
\hline Female(A) & $19.78^{\mathrm{b}}$ & \pm 0.65 & $27.32^{\mathrm{b}}$ & \pm 0.71 \\
\hline Male(B) & $17.80^{\mathrm{a}}$ & \pm 0.61 & $25.54^{\mathrm{a}}$ & \pm 0.66 \\
\hline Birth type &
\end{tabular}

$\mathrm{A}, \mathrm{B} \leq 0.01 ; \mathrm{a}, \mathrm{b}, \mathrm{c}, \mathrm{d} P \leq 0.05 ;$ 
Table 3. Phenotypic correlations (above) and genetic correlations (below) between body weight of lambs

\begin{tabular}{|c|c|c|c|c|}
\hline \multirow[t]{2}{*}{ Traits of dam } & \multicolumn{4}{|c|}{ Traits of lambs } \\
\hline & BWB & BW30 & BW60 & BW90 \\
\hline BWB & - & $0.879 * *$ & $0.639 * *$ & $0.449^{*}$ \\
\hline BW30 & $0.827 * *$ & - & $0.641 * *$ & 0.395 * \\
\hline BW60 & $0.494^{*}$ & $0.488^{*}$ & - & $0.426 *$ \\
\hline BW90 & $0.320^{\text {n.s }}$ & $0.251^{\mathrm{n} . \mathrm{s}}$ & $0.284^{\mathrm{n} . \mathrm{s}}$ & - \\
\hline
\end{tabular}

n.s. Correlation was not significant, ${ }^{* *}$ Correlation is significant at the 0.01 level, ${ }^{*}$ Correlation is significant at the 0.05 level

\section{Conclusions}

The evaluation of the effect of genotype on growth showed that this factor have a significant effect on the growth traits under study. Sex of lamb had a significant effect at birth and very significant effect at 30 days, but had no significant effect on weight at 60 (BW60) and 90 (BW90) days.Type of birth has significant effect on the body weight from birth to weaning and the highest body weights were recorded in singles. Phenotypic correlations indicated a positive and very highly significant effect on the growth traits. Genetic correlations were less and not significant between all observed ages of lambs.

\section{Acknowledgement}

This study is part of the projects TR 31053 "Modern biotechnology solutions in the breeding and feeding of cattle sheep and goats for the production of valuable and safety food" and TR 31001 "An environmental approach and implementation of modern biotechnologies as a basis for the improvement of ruminant breeding technology", and financially supported by the Ministry of Education, Science and Technological Development of the Republic of Serbia. 


\title{
Ocena fenotipskih i genetskih trendova osobina porasta lipske i svrljiške rase ovaca
}

\author{
V. Caro Petrović, M. P. Petrović, M. M. Petrović, Z. Ilić, N. Maksimović, D. Ružić \\ Muslić, N. Stolić
}

\section{Rezime}

Važniji fenotipski i genetski trendovi osobina porasta jagnjadi su ispitivani. Istraživanje je obuhvatilo jaganjce dveju lokalnih rasa ovaca: Lipska (LP) i Svrliška (SV). Sva jagnjad su merena prvi put na rođenju (BVB) i nakon toga redovno na dve nedelje. Na osnovu rezultata merenja telesne težine (BW) su prilagođene prosečnoj starosti 30 (BW30), 60 (BW60) i 90 dana (BW90). Rezultati uticaja genotipa na rast su pokazali vrlo značajan uticaj. Pol jagnjadi ima značajan efekat na rođenju i veoma značajan efekat sa 30 dana, ali nije imao značajan uticaj na masu sa 60 (BW60) i 90 (BW90) dana. Tip rođenja ima značajan uticaj na telesnu masu od rođenja do zalučenja, a veće mase su zabeležene kod jedinaca. Fenotipske korelacije su pozitivne i vrlo visoko značajne između osobinaprirasta. Genetske korelacija bile su značajne, ali ne i između svih posmatranih perioda uzrasta jagnjadi.

\section{References}

ABEGAZ S., VANWYK J. B., OLIVIER J J. (2005): Model comparisons and genetic and environmental parameter estimates of growth and the Kleiber ratio in Horro sheep, S. Afr. J. Anim. Sci. 35: 3040.

BEHZADI, R., SHAHROUDI, F. E. AND VAN VLECK, L. D. (2007): Estimates of genetic parameters of growth traits in Kermani sheep. J. Animal Breeding and Genetic. 5: 296- 301.

DASS G, PRASAD H, MANDAL A, SINGH MK, SINGH N.P. (2008): Growth characteristics of Muzaffarnagari sheep under semi-intensive feeding system. Indian J. Anim. Sci., 78(9): 1032-1033.

DIXIT S.P., DHILON JS., SING G. (2001): Genetic and non-genetic parameter estimates for growth traits of Bharat Merino lambs. Small Rumin. Res. 42: 101104.

EL FADILLI M., MICHAUX C., DETILLEUX J., LEROY PL. (2000): Genetic parameters for growth traits of the Moroccan Timahdit breed of sheep. Small Rumin. Res. 37: 203-208. 
FERNANDES A.A.O., BUCHANAN D., SELAIVE-VILLARROEL A.B. (2001): Environmental effects on growth rate of Morada Nova hair lambs in northeastern Brazil. Rev. Bras. Zoot., 30, 1460-1465.

HARVEY W. R.(1991): Mixed Model Least Squares and Maximum Likelihood Computer Program. The Ohio State Univ. Columbus, OH, USA.

KUCHTÍK J., DOBEŠ I. (2006): Effect of some factors on growth of lambs from crossing between the Improved Wallachian and East Friesian. Czech J. Anim. Sci., 51, 54-60.

LAES-FETTBACK C., PETERS K. J. (1995): A comparative study of performance of Egyptian goat breeds. II. Growth performance and productivity. Arch. Tierz., Dummerstorf. 38: 563-575.

MANDAL A., PANT K. P., NANDY D. K., ROUT P. K. AND ROY R. (2003):Genetic analysis of growth traits in Muzaffarnagari sheep. Tropical Animal Health and Production. 35: 271-284.

MARGETÍN M., CAPISTRÁK J., ŠPANIK J., APOLEN D., BULLOVÁ M. (2004): Intenzita rastu jahniat rôzných genotypov vytváranych na báze plemena zošlachtena valaška. In: Sbor. přednášek z mezinárodní konference a setkání chovatelů ovcí a koz, Ovce - kozy, Seč. 72-75.

NOTTER D. R., KELLY R. F., MCCLAUGHERTY F. S.(1991). Effects of ewe breed and management system on efficiency of lamb production. II. Lamb growth,survival and carcass characteristics. J. Anim. Sci. 69: 22-33.

PETROVIC P. M., RUZIC MUSLIC D., CARO PETROVIC V., MAKSIMOVIC N. (2011). Influence of environmental factors on birth weight variability of indigenous Serbian breeds of sheep. African Journal of Biotechnology. 10: 46734676.

PETROVIĆ P. M. (2007): Sustainable sheepbreeding. Institute for Animal Husbandry, Belgrade, $256 \mathrm{p}$.

SUAREZ V.H., BUSETTI M.R. GARRIZ C.A., GALLINGER M.M., BABINEC F.J. (2000): Pre-weaning growth, carcass traits and sensory evaluation of Corriedale, Corriedale $\times$ Pampinta and Pampinta lambs. Small Rumin. Res., 36, 85-89.

UGARTE E.(2007): The Breeding program of Latxa Breed. 2nd International Congress, Belgrade, October 3-5, 2007 Biotechnology in Animal Husbandry, 5-6, 97-111. 